Ann. Biol. anim. Bioch. Biophys., 1977, 17 (3 B), 441-452.

\title{
Prolactin release in response to nursing or milking stimulus in the ewe. Is it mediated by thyrotrophin releasing hormone?
}

\author{
par G. KANN, R. HABERT *, Chantal MEUSNIER, Hélène Sophie RYNIEWICZ ** \\ Laboratoire de Physiologie de la Lactation, I.N.R.A. \\ 78350 Jouy-en-josas, France.
}

\begin{abstract}
Summary. Stimulation of the mammary gland during hand or mechanical milking or during nursing is followed by an abrupt surge of prolactin in lactating ewe. This rapid increase of prolactinaemia is due to a secretion reflex originating in the teat nerve endings since dernervation of the mammary gland suppresses the surge induced by milking or nursing.

Although intravenous injection of TRH can mimic the prolactin surge observed during milking, the possible role of this hypothalamic factor in prolactin secretion during mammary stimulation is not demonstrated.
\end{abstract}

The role of prolactin in promoting milk production during lactation is one of the best established functions in female mammalians (Cowie and Tindall, 1971 ; Denamur, 1971). In this paper we present the results of our investigations on the nature and the regulation of prolactin release after stimulation of lactating ewe mammary gland. Most recent experiments on prolactin regulation during nursing have been performed on the polytocous female rat (Terkel ef al., 1973 ; Kordon et al., 1973 ; Mena ef al., 1976). We propose that the ewe might be a model for females having one or two young at each parturition.

\section{Materials and methods.}

Hormonal determination.

Ovine prolactin was measured with a specific double antibody radioimmunoassay (Kann, 1971). Ovine prolactin supplied by the NIH (PS7 $24 \mathrm{lU} / \mathrm{mg}$ ) was used for labelling and as standard preparation. Sensitivity of the assay allowed the detection of $0.2 \mathrm{ng} / \mathrm{nl}$ of ovine prolactin.

* Laboratoire de Physiologie, Université Paris VII, 2, place Jussieu, 75005 Paris.

** Polish Academy of Sciences, Institut of Genetics and Animal Breeding, Jastrzebiec, Warsaw, Poland. 
TSH was measured with a double antibody radioimmunoassay (Freychet ef al., 1969). Ovine TSH (30 IU/mg) purified by $Y$. A. Fontaine was used as radioactive tracer and as standard preparation. Sensitivity of the assay was $9 \mu \mathrm{IU} / \mathrm{ml}$.

\section{Animals.}

All animals used in experiments reported here were of the french « Préalpes du Sud $\gg$ breed in their first or second lactation period. Sheep were trained to be handled so as to avoid effects of eventual stress, and several blood samples were collected and discarded prior the experimental period to accustom animals to venipuncture.

\section{Surgical techniques.}

Mammary denervation has been described by Denamur and Martinet (1959). It involved the excision and then the reattachment of the mammary gland of pregnant ewes. Bilateral denervations were performed in 2 stages : the first operation wos carried out on one side on the 100th day of pregnancy, the second on the other side 2 weeks later. When denervation was done during lactation, we severed the first $L_{1}$ to $L_{4}$ lumbar nerves, the perineal nerve and the lumbar sympathetic system of early lactating ewes either unilaterally or bilaterally.

Thyroidectomy was performed by a classical approach (Theriez, 1962) with special attention to the ablation of the isthmus which is barely visible in sheep.

\section{Results.}

Pattern of plasma prolactin after teat stimulation of lactating ewes.

Typical patterns of prolactin discharge after different stimuli applied to the udder of a lactating ewe are represented on figure 1. All prolactin values after nursing were obtained at 9 a.m., the lamb having been separated from the ewe $2 \mathrm{~h}$ before experimentation. Nursing lasted 4-5 min and the lamb was taken away thereafter in order to prevent other stimulations during further blood sampling, 5, 10, 15, 25, 45, 60, 90 and 120 min later. After weaning (55th day) blood samples were obtained at similar times after hand milking (duration $2 \mathrm{~min}$ ).

A brisk and transient increase in the concentration of prolactin is observed after application of the suckling or milking stimulus to the teats as has been already described (Fell ef al., 1972 ; McNeilly, 1972 ; Kann ef al., 1973).

Prolactin reached an acme in 5-10 min and a rapid decrease was observed immediately after. It was apparently in agreement with the half-life of prolactin ( $20 \mathrm{~min})$ in lactating ewe as measured by disappearance of prolactin in plasma after hypophysectomy (Kann and Denamur, unpublished results).

Similar patterns have been described in the goat and the cow (Johke, 1969 ; Bryant ef al., 1970 ; Schams, 1972). The fact that prolactin values, unlike those in lactating rat, decreased very quickly after having reached a transient peak, was probably the consequence of a brief stimulus as suggested by Grosvenor and Withworth (1974). For instance, a short stimulus induced by hand milking $(2 \mathrm{~min})$ resulted in a earlier prolactin peak (fig. 1) than when induced by suckling (lasting 4 to $6 \mathrm{~min}$ ). 
Evolution of prolactin surges induced by teat stimulation at different stages of lactation period.

As evidence, the prolactin discharge observed after the mammary gland stimulation declined as lactation period lengthened (fig. 1). Prolactin increments obtained by measuring the area beneath prolactin response during $30 \mathrm{~min}$ after hand milking of two lactating ewes are presented on figure 2. As the time after parturition passed, the amount of prolactin released progressively rose to a maximum value during the second decade of milking period and then dropped quickly. After 3 months of lactation there

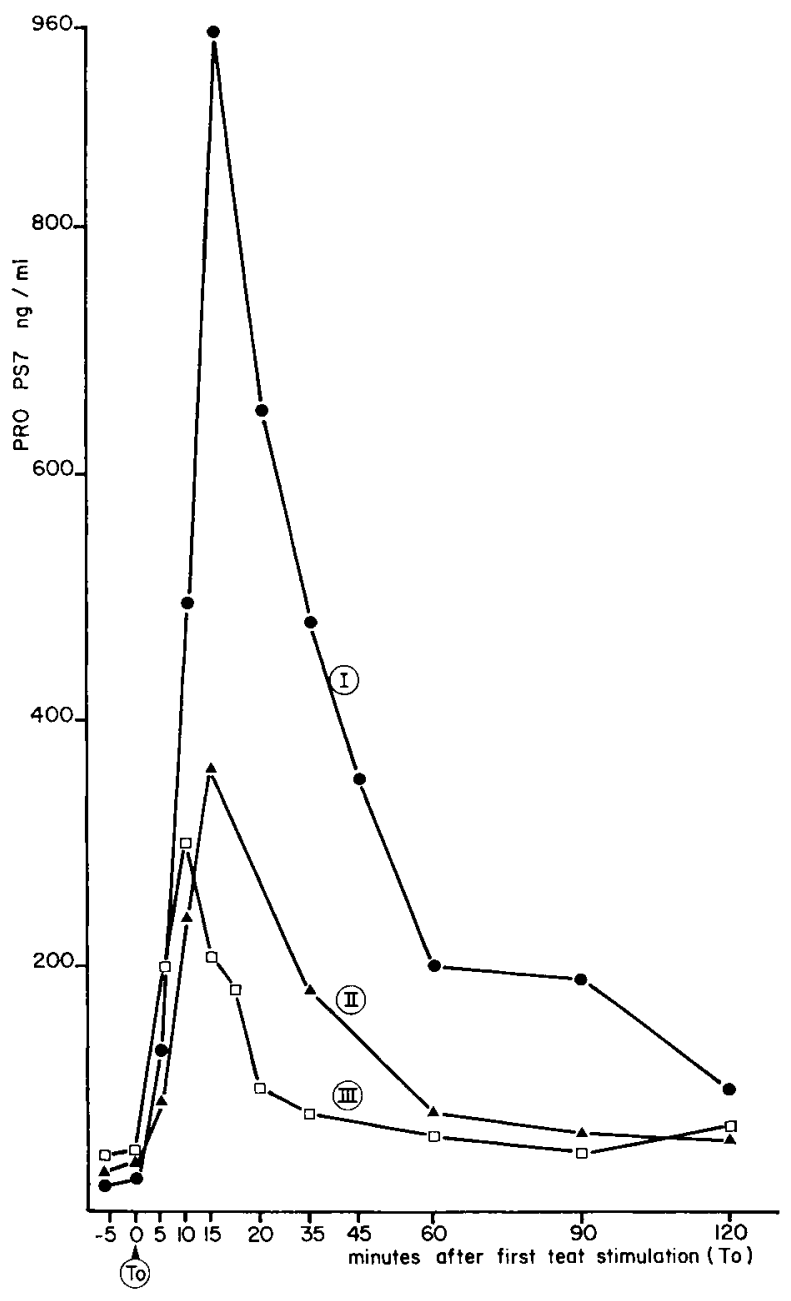

FIG. 1. - Prolactin plasma levels affer stimulation of ewe 7420 (1 lamb born 9.12.1973).

1. After nursing stimulus on the 9th day of lactation.

II. After nursing stimulus on the 33th day of lactation.

III. After hand milking on the 62th day of lactation. 
was no more release of prolactin during milking. The evolution of prolactin levels when ewes were freely nursing their lambs throughout lactation is shown on figure 3 : high values of hyperprolactinaemia in these cases were due to the fact that immobilization of the ewes for blood sampling, was always followed by energic lamb suckling.

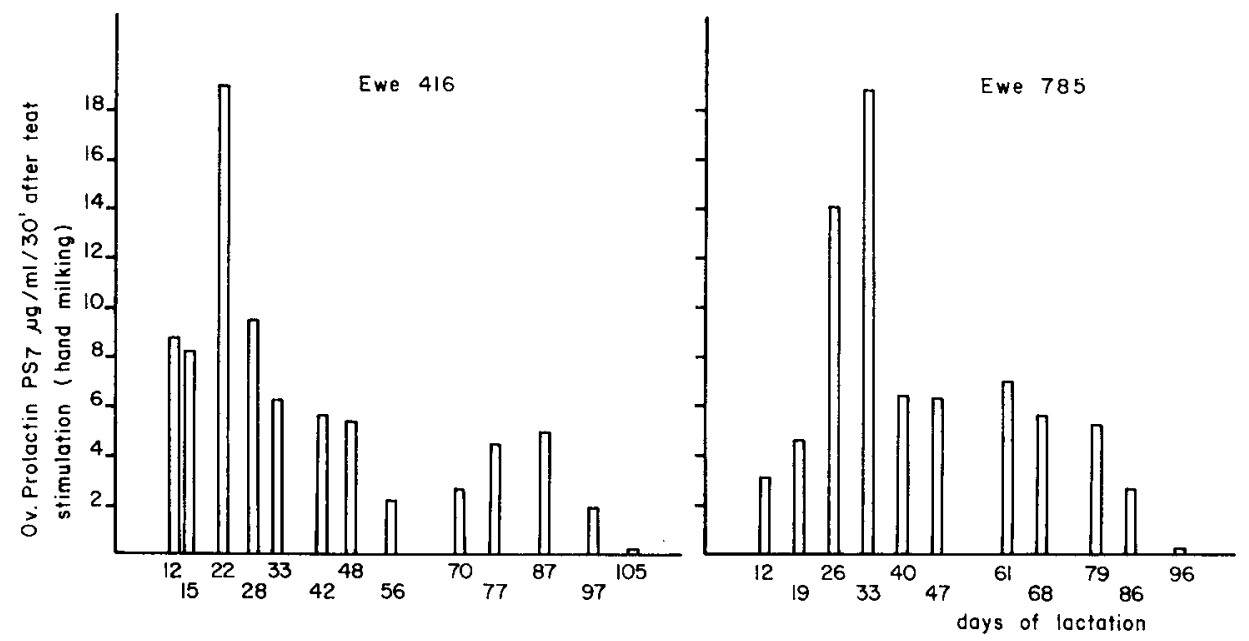

FIG. 2. - Prolactin increments measured during $30 \mathrm{~min}$ ofter handmilking as milking period progressed in plasma of two lactating ewes (computed from the area under prolactin curve).

Nevertheless, as lactation continued, it was clear that mean values of prolactin levels dropped in the same way as during hand milking. Similar patterns have been observed in the ewe by MacNeilly (1972), in the cow by Koprowski and Tucker (1973) and in the goat by Hart (1972).

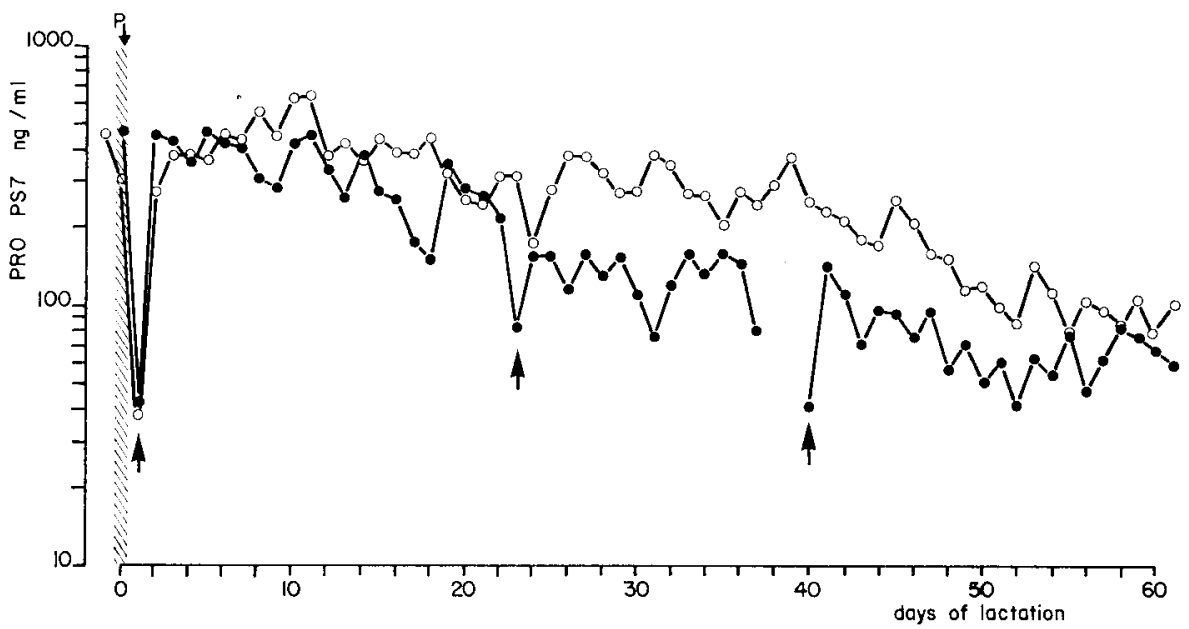

FIG. 3. - Prolactin plasma levels (2-4 samples/day) in two nursing ewes. Arrows indicate prolactin depletion due to preoperative fasting before ovarioscopy. $\mathrm{P}=$ parturition time. 
In preliminary studies we were not able to correlate either basal prolactin values or prolactin peaks to normal milk yields. Nevertheless animals with very poor milk yields were often found to have normal basal prolactin values (whatever the season i.e. $20-50 \mathrm{ng} / \mathrm{ml}$ ) but to have weak or absent responses to the suckling or milking stimulus, even during the early postpartum.

Ascending pathway for prolactin release after teat stimulation.

As one could suspect, sensitive receptors from the teat are the origin of the efferent arc of a neuroendocrine reflex during milking or suckling : bilateral denervation of the lactating ewe mammary gland results in a complete disappearance of prolactin release when teats are stimulated either by machine- or hand-milking or by suckling (fig. 4).

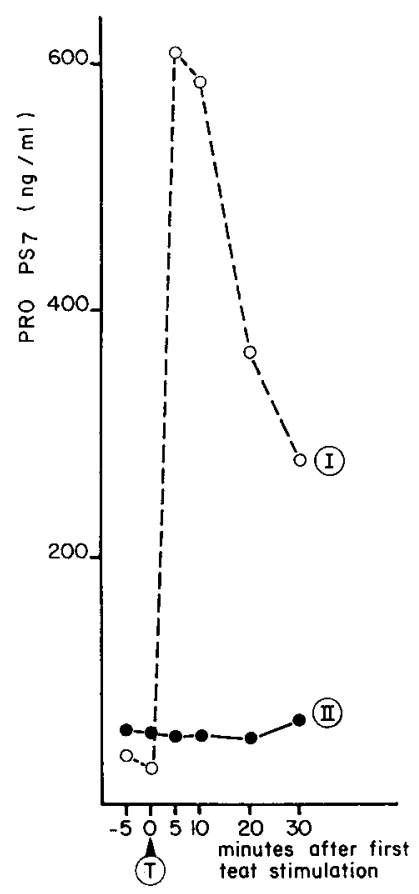

FIG. 4. - Prolactin plasma levels after hand milking.

I. (dotted line, open circles) on day 18 of lactation (19.7.1972).

II. (full line, closed circles) on day 25 of lactation (29.7.1972) after fotal denervation of the udder.

The unilateral section of the efferent nerves issuing from the mammary gland demonstrated that the spinal reflex, resulting in a prolactin surge after teat stimulation was ipsilateral (fig. 5). Hemisection or total section of the dorsal mesullar sensitive tracts gave similar results to the partial or total udder denervation when performed at the 12th dorsal nerve level. If section of medullar posterior sensitive tracts was performed at the 5 th lumbar nerve level, the reflex (i.e. prolactin secretion after milking 
or suckling) was unaltered and this could be considered as a « sham operation 》. Exteroceptive stimuli such as seeing the milker, hearing the milk pails or the milking machine running, etc... were not successful in inducing a prolactin reflex in lactating ewes as described for the nursing rat by Grosvenor and Mena (1967).

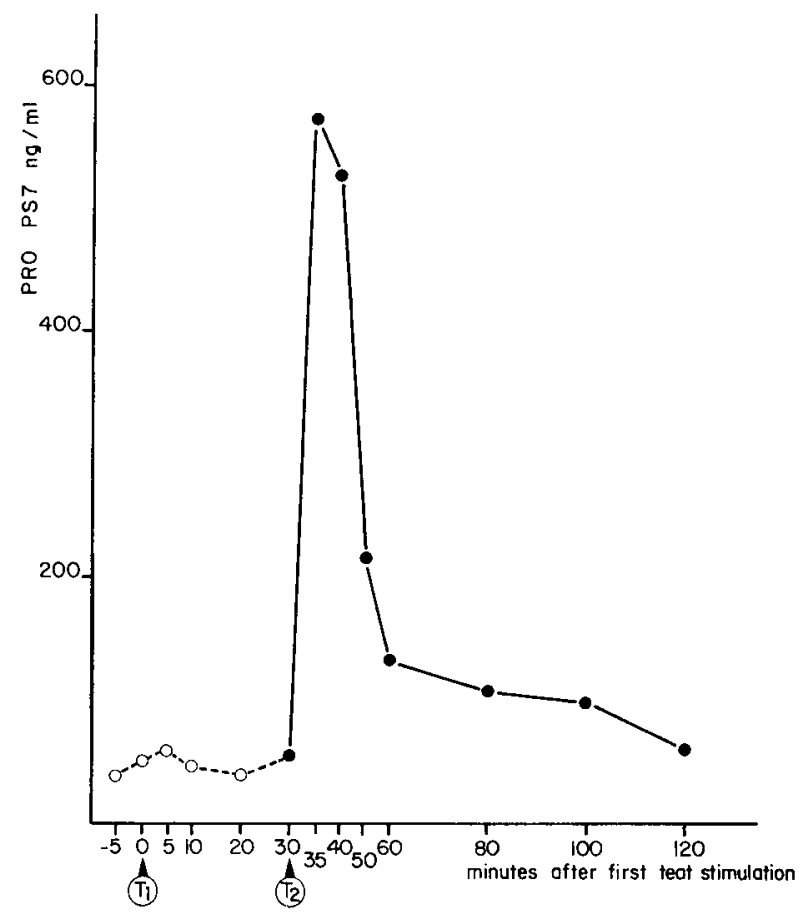

FIG. 5. - Prolactin plasma values after teat stimulation of a lactating ewe with left side of the udder denervated.

I. (dotted line, open circles) after stimulation of left teat $\left(T_{1}\right)$ on day 19 of lactation (16.7.1972).

II. (full line, closed circles) after stimulation of right teat $\left(\mathrm{T}_{2}\right)$.

Is thyrotrophin-releasing hormone physiologically related to prolactin milking reflex of lactating ewe?

The inhibitory influence played by the hypothalamus on prolactin secretion has been recognized since Pasteels (1961) and Talwalker et al. (1963) and Prolactin Inhibiting Factor (PIF) has been localised in the hypothalamus of rat, sheep, cattle, pig and human, but has not been chemically isolated. On the other hand, persistent reports gave support to the fact that hypothalamic extracts contained a Prolactin Releasing Factor (PRF) (Florindo and Nicoll, 1969 ; Amenomori and Meites, 1970). In 1971, Tashjian et al. reported that Thyrotrophin Releasing Hormone (TRH) could stimulate prolactin secretion from rat pituitary cells in culture and this was confirmed by ultrastructural studies of Gourdji et al. showing changes with secretory activity in cells. TRH could also be active in vivo : in 1973 we reported that, as in many other species, TRH 
could stimulate prolactin a very short time after an intrajugular administration (Kann et al., 1973).

Low doses of TRH were able to stimulate a prolactin release and $3 \mu \mathrm{g}$ of TRH induced a prolactin surge which mimicked the suckling reflex in normal or spayed lactating ewes. In some cases where this prolactin reflex was very poor, TRH was as potent as in normal animals to induce a prolactin response. This indicated that in ewes with low prolactin reflex after milking, sensitivity of the mammary gland nerve endings was affected more than hypothalamic deficiency. Action of TRH on prolactin resulted from a direct action at the pituitary level since TRH was able to induce prolactin elevation in animals with pituitary stalk section (fig. 6). After milking or suckling we were not able to show any modification of TSH in contrast to what was observed after TRH administration (Kann ef al., 1973). This indicated that if TRH was involved in prolactin release during the milking reflex, it was more effective on prolactin than on TSH.
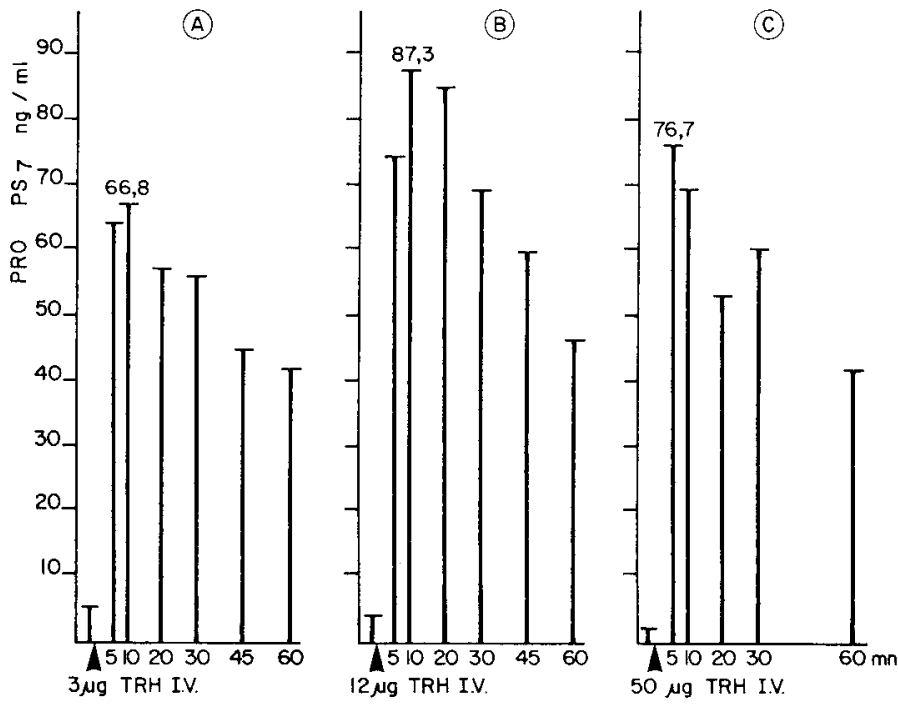

FIG. 6. - Prolactin plosma values after administration of TRH to an ewe after pituitary stalk section.

A. 6 days after stalk section ( $3 \mu \mathrm{g}$ IV)

B. 7 days after stalk section (12 $\mu \mathrm{g}$ IV)

C. 8 days after stalk section $(50 \mu \mathrm{g} I V)$

According to Silverman and Knigge (1972) an increase in endogenous TRH release could be expeted after thyroidectomy and ought to modify prolactin secretion if TRH was a physiological mediator of prolactin secretion : we noted an imporiant increase in TSH one month after thyroidectomy of ewes but no change either in basal prolactin values (fig. 7) or in prolactin release after teat stimulation by milking (fig. 8).

Since increase of TRH release by the hypothalamus after thyroidectomy remained uncertain we checked the assumption that TRH could be a PRF with another experimental protocol : in 4 lactating ewes we measured at $48 \mathrm{~h}$ intervals prolactin incre- 
ments resulting from hand-milking stimulation at 6.30 a.m., 9.30 a.m., 2 p.m., 4 p.m. and 6 p.m. (experiment A). During the interval days, ewes were milked twice daily at 6.30 a.m. and p.m.

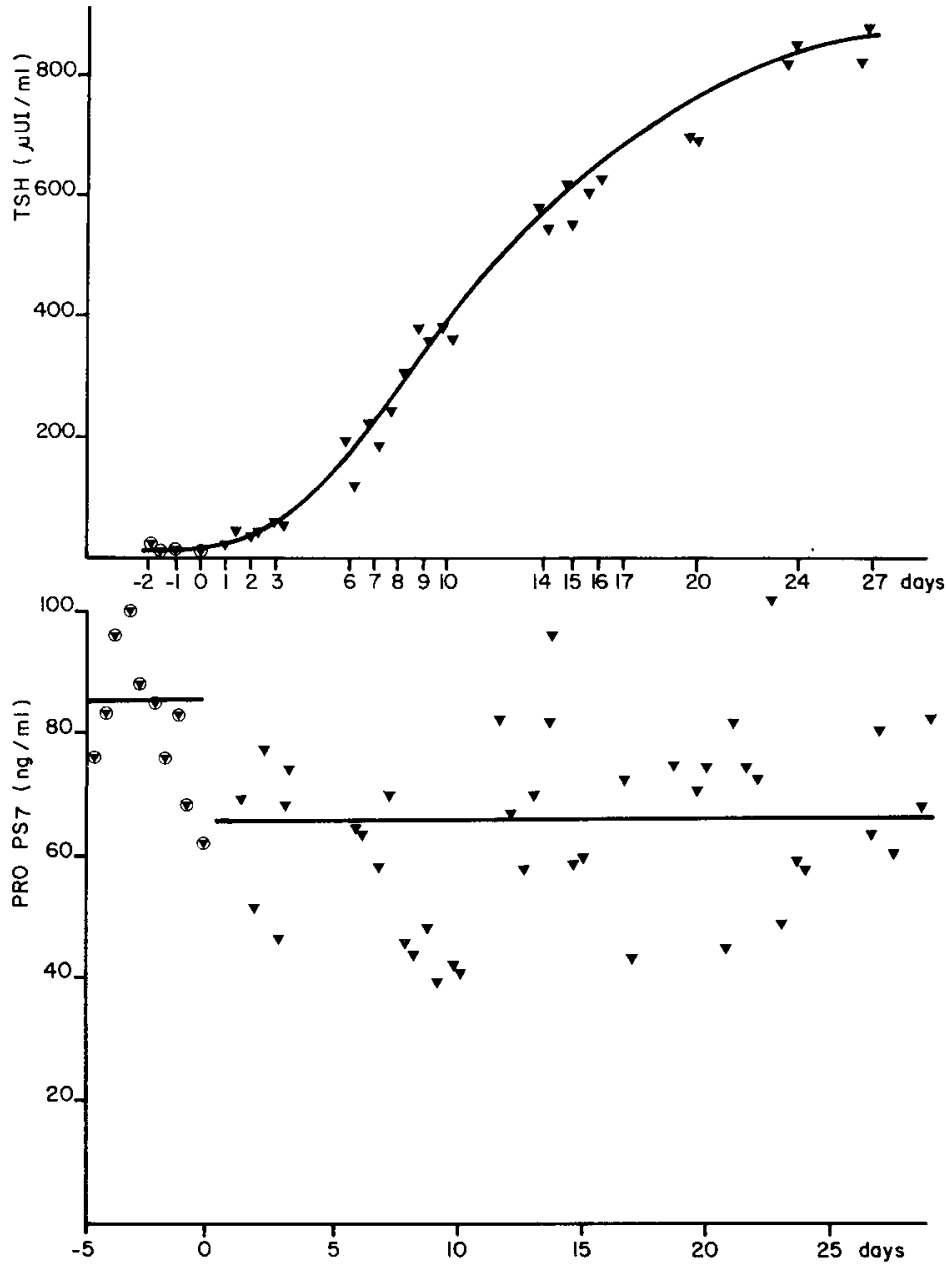

FIG. 7. - Mean prolactin and TSH basal levels (4 ewes) after thyroidectomy (2 samples/day July 1973).

Experiment $B$ was conducted in the same way as experiment $A$, but hand milkings at 9.30 a.m., 2 p.m. and 4 p.m. were substituted by intravenous administration of $6 \mu \mathrm{gr}$ TRH.

As can be observed on figure 9, the prolactin surge induced by hand milking at 6.30 a.m. is most abundant when the ewe is milked 5 times a day. This probably reflects the non-stimulation of the hypophysis for 12 hours. The subsequent mammary 

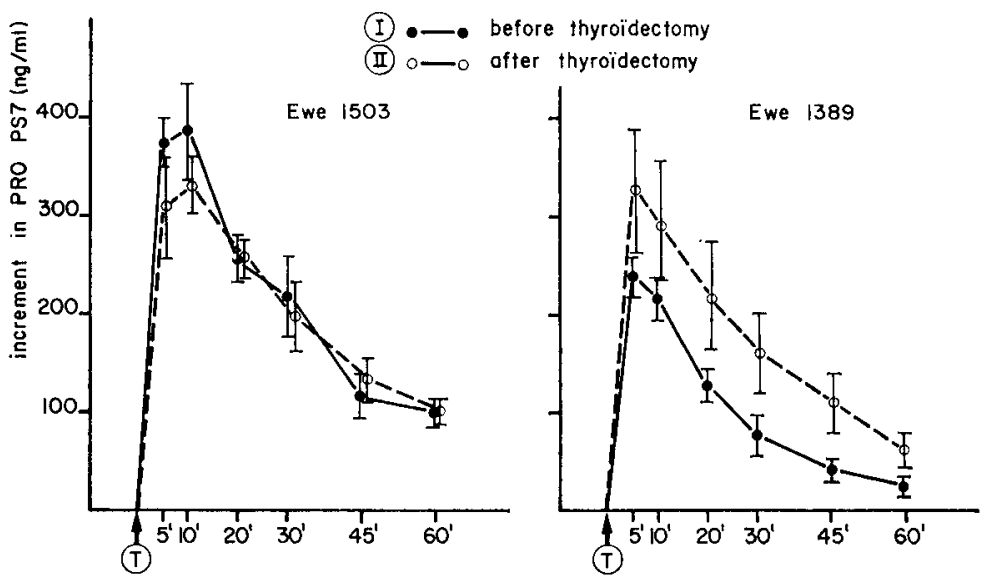

FIG. 8. - Increments of prolactin induced by hand milking in two lactating ewes before and after thyroidectomy.

I. (full line, closed circles) before thyroidectomy (mean values measured 11, 6, 4 and 1 days before operation).

II. (dotted line, full circles) after thyroidectomy (mean values measured 2, 7, 15 and 30 days after operation).

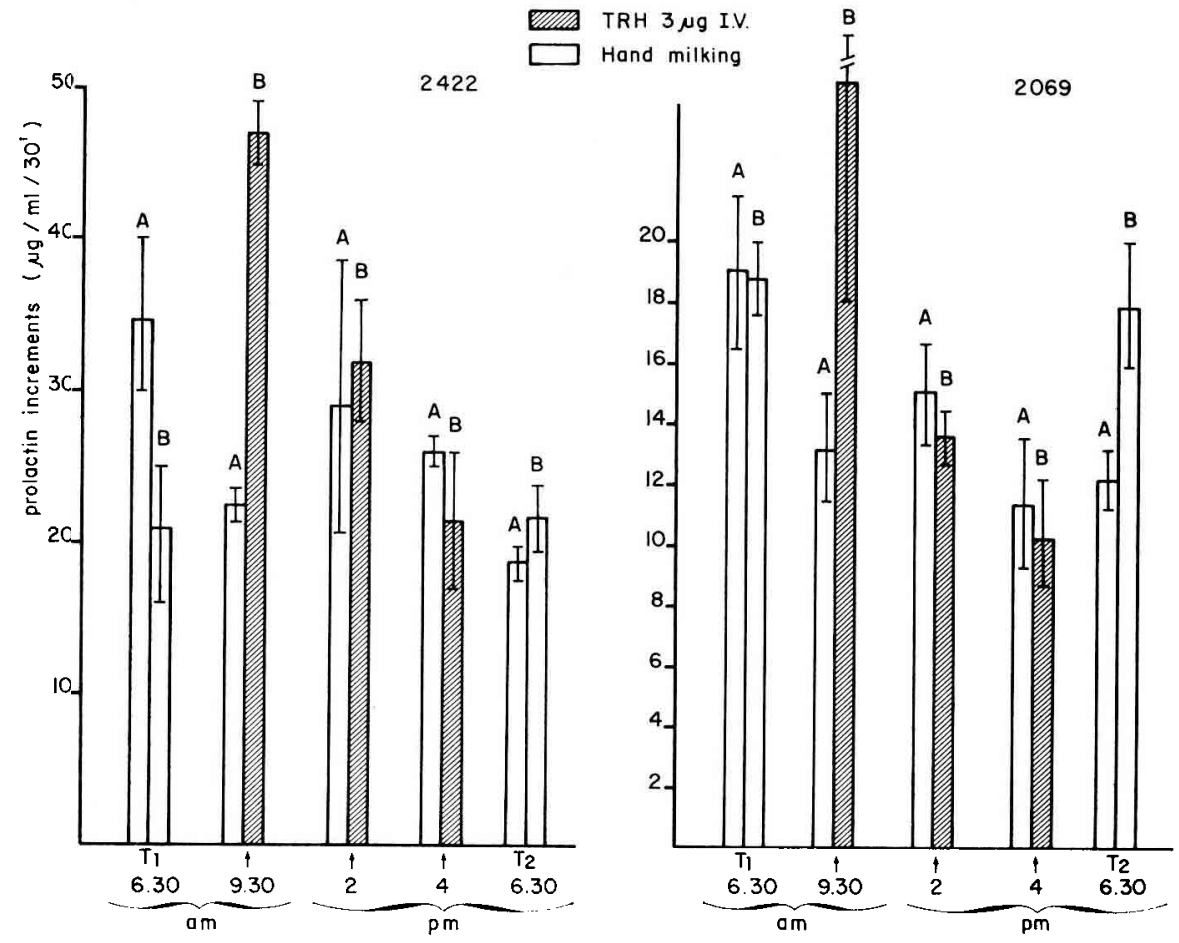

FIG. 9. - Increments of plasma prolactin after iterative stimulation in 2 lactating ewes (mean values of 3 measurements $\pm \mathrm{SE}$ ).

A. After hand milking at 6.30, 9.30 a.m., 2, 4 and 6.30 p.m.

B. After hand milking at 9.30 a.m. ( $\left.T_{1}\right)$ TRH administration at 9.30 a.m., 2, 4 p.m. and lastly, hand milking at 6.30 p.m. $\left(\mathrm{T}_{2}\right)$. 
gland stimulation resulted in surges of prolactin which were smaller but similar to one another.

On the other hand, administration of TRH three times a day (experiment B) resulted in progressively depressed responses. This indicates probably a saturation of hypophysial prolactin cell receptors with TRH. If the prolactin surge observed after that stimulation at 6.30 p.m. (after 3 TRH stimulations) was only due to an endogenous enhancement of TRH, it ought to be less important than the prolactin increment observed at 4 p.m. after the last TRH injection. As can be observed on figure 9 it was on the contrary more important or equivalent. Therefore, we were not able in this experiment as in others, to connect the prolactin reflex after milking stimulus to any enhancement in TRH release. In hypothalamic extracts, PRF activity and TRH activity were located in different fractions after gel chromatography (Valverde ef al., 1972). Moreover the fact that dopamine antagonists such as $2 \mathrm{Br} \alpha$ ergocryptin (i.e. PIF releasers) could completely impair the prolactin response either to mammary gland stimulation or to TRH exogenous administration (Schams, 1972b; Kann, 1976) confirmed a major control of prolactin release through inhibitory actions.

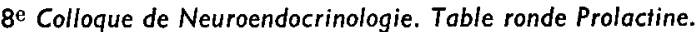

Tours, 7 septembre 1976.

Résumé. Après stimulation de la glande mammaire lors de la traite manuelle, mécanique ou lors de la tétée, on observe une brutale décharge de prolactine chez la brebis en lactation. Cette augmentation rapide de la prolactinémie est due à une sécrétion réflexe ayant son origine dans les terminaisons nerveuses du trayon, puisque la dénervation de la glande mammaire supprime la décharge induite par la traite ou la tétée.

Bien que l'administration intraveineuse de TRH soit capable de mimer la décharge de prolactine observée lors de la traite, il ne nous a pas été possible de démontrer un éventuel rôle de ce facteur hypothalamique pour permettre la sécrétion de prolactine lors de la stimulation mammaire.

\section{References}

AMENOMORI Y., MEITES J., 1970. Effects of a hypothalamic extract on serum prolactin levels during the estrus cycle and lactation. Proc. Soc. exp. Biol. Med., 134, 492-495.

BRYANT G. D., LINZELL J. L., GREENWOOD, F. C., 1970. Plasma prolactin in goats measured by radioimmunoassay. The effects of teat stimulation, mating behaviour, stress, fasting and of oxytocin, insulin and glucose injections. Hormones, 1, 26-35.

COWIE A. T., TINDAL J. S., 1971. The physiology of Jactation. Edward Arnold, London.

DENAMUR R., 1971. Hormonal control of lactogenesis. J. Dairy Res., 38, 237-264.

DENAMUR R., MARTINET J., 1959. Rôle du système nerveux de la glande mammaire dans l'entretien de la laciation. Arch. Sci. physiol., 13, 271-352.

FELL L. R., BECK C., BROWN J. M., CATT K. J., CUMMING I. A., GODING J. R., 1972. Solid-phase radioimmunoassay of ovine prolactine in antibody-coated tubes. Prolactin secretion during estradiol treatment, at parturition, and during milking. Endocrinology, 91, 1329-1336.

FIORINDO R. P., NICOLL C. S., 1969. Inhibitory and stimulatory effects of rat median eminence extract on prolactin secretion in vitro by rat adenohypophysis. Fed. Proc., 28, 437.

FREYCHET P., PELLETIER J., ROSSELIN G., 1969. Dosage de l'hormone thyréostimulante hypophysaire ovine à l'aide d'un système radioimmunologique bovin. Ann. Biol. anim. Bioch. Biophys., 9, 483-496. 
GOURDJI D., KERDELHUE B., TIXIER-VIDAL A., 1972. Ultrastructure d'un clone de cellules hypophysaires sécrétant de la prolactine. Modifications induites par le TRF. C. R. Acad. Sci., Paris, $D, 274,437-440$.

GROSVENOR C. E., MENA F., 1967. Effect of auditory olfactory and optic stimuli upon milk ejection and suckling induced release of prolactin in lactating rat. Endocrinology, 80, 840-846.

GROSVENOR C. E., WHITWORTH N., 1974. Evidence for a steady rate of secretion of prolactin following suckling in the rat. J. Dairy Sci., 37, 900-904.

HART I. C., 1972. Level of prolactin in the blood of the goat during milking, throughout lactation and over a $24 \mathrm{~h}$ period. J. Endocr., 55, xxviii.

JOHKE T., 1969. Prolactin release in response to milking stimulus in the caw and goat estimated by radioimmunoassay. Endocr. jap., 16, 179-185.

KANN G., 1971. Radioimmunoassay of plasma prolactin in sheep. C. R. Acad. Sci., Paris, D, 272, 2808-2811.

KANN G., 1976. Inhibition of prolactin secretion in the ewe by $2 \mathrm{Br}$ ergocryptin during pregnancy or early lactation ; effect on milk yield. 5 th Int. Congr. Endocr., Hamburg, Abst. 611.

KANN G., HABERT R., DENAMUR R., 1973. Concentrations plasmatiques de la prolactine et de I'hormone thyreostimulante au cours de la traite des brebis : comparaison avec les effets du TRH. C. R. Acad. Sci., Paris, D, 276, 1321-1324.

KOPROWSKI J. A., TUCKER H. A., 1973. Serum prolactin during various physiological states and its relationship to milk production in the bovine. Endocrinology, 92, 1480-1487.

KORDON C., BLAKE C. A., TERKEL J., SAWYER C. H., 1973. Participation of serotonin containing neurons in the suckling induced rise in plasma prolactin levels in lactating rats. Neuroendocrinology, 13, 213-223.

LU K. H., CHEN H. T., HUANG H. H., GRANDISON L., MARSHALL S., MEITES J., 1976. Relation between prolactin and gonadotrophin secretion in post partum lactating rat. J. Endocr., 68, 241-250.

MCNEILLY J., 1972. Observations on the pattern of prolactin release during suckling in the ewe. J. Reprod. Fert., 31, 487-488.

MENA F., ENJALBERT A., CARBONELL L., PRIAM M., KORDON C., 1976. Effect of suckling on plasma prolactin and hypothalamic monoamine levels in the rat. Endocrinology, 99, 445-451.

PASTEELS J. L., 1961. Sécrétion de prolactine par l'hypophyse en culture de tissus. C. R. Acad. Sci., Paris, D, 134, 1049-1054.

SCHAMS D., 1972a. Prolactin levels in bovine blood influenced by milking manipulation, genital stimulation and oxytocin administration with specific consideration to the seasonal variations. Acta endocr., 71, 684-696.

SCHAMS D., 1972b. Prolactin releasing effects of IRH in the bovine and their depression by a prolactin inhibitor. Horm. Metab. Res., 4, 405.

SILVERMAN A. J., KNIGGE K., 1972. Transport capacity of median eminence. II. Thyroxine transport. Neuroendocrinology, 10, 71-82.

TALWALKER P. K., RATNER A., MEITES J., 1963. In vitro inhibitor of pituitary prolactin synthesis and release by hypothalamic extract. Amer. J. Physiol., 205, 213-218.

TASHJIAN A. H., BAROWSKI N. J., JENSEN D. K., 1971. Thyrotropin releasing hormone : direct evidence for stimulation of prolactin production by pituitary cells in culture. Biochem. biophys. Res. Comm., 43, 516-523.

TERKEL J., BLAKE C. A., SAWYER C. H., 1973. Serum prolactin levels in lactating rats after suckling or exposure to ether. Endocrinology, $91,49$.

THERIEZ C., 1962. Action des hormones thyïoidiennes sur la croissance en longueur du brin de laine. Thèse $3^{\mathrm{e}} \mathrm{cycle}$, Paris.

VALVERDE C., CAIEFFO R. V., REICHLIN S., 1972. Prolactin-Releasing-Factor in porcine and rat hypothalamic tissue. Endocrinology, 91, 982-993. 